\title{
22. 難聴耳における恥覚不快レベルの動態
}

\author{
山本渉・。斉藤瑛・大塚護
}

はじめに

以前より德賞の快適レベルや不快レベルが loudnessに関係するのではないかという考光方があつたが， 広く日常的に利用されるには至つていない，わたくし 達は，聴覚の機能をより正確につかむためには，au一 ditory area 全体として正しくとらえる必要がある のではないかという考えで，不快レベルの測定を行な つてきている，そして，ての方法が臨床的に有效であ り再検討に值するものではないかという印象をうけて いるが，こてではその臨床的な応用について問題にな る点のいくつかを明らか机することを試みたしだいで ある。

\section{判定装目と方法}

通常のオーシオメータで，不快レベルを測定しよう とすると, 特に難聴耳においては, 出力が不足する ことが少なくないので,リオンオーシオメータ A一 1002DにブースタA E25を接続して測定を行なつてい る。このブースタを使用すると，測定範囲は $125 \mathrm{~Hz}$ $90 \mathrm{~dB}, 250 \mathrm{~Hz}$ で $105 \mathrm{~dB}, 500 \mathrm{~Hz}, 1000 \mathrm{~Hz}$ および 2000 $\mathrm{Hz}$ で $120 \mathrm{~dB} ， 4000 \mathrm{~Hz}$ で $115 \mathrm{~dB}, 8000 \mathrm{~Hz}$ では $100 \mathrm{~dB}$ ま で拡大することができる。

測定方法は $1000 \mathrm{~Hz}$ より始め $5 \mathrm{~dB}$ step の上显法によ つて，不快感觉える最小值を不快レベルとしている， 順序は左右耳を交互に測定しながら, 通常の最小可聴 域值の測定法にならつて $1000 \mathrm{~Hz}, 2000 \mathrm{~Hz}, 4000 \mathrm{~Hz}$, $8000 \mathrm{~Hz}, 500 \mathrm{~Hz}, 250 \mathrm{~Hz}, 125 \mathrm{~Hz}$ の各周波数について 不快レベルを求めている.

\section{成}

\section{綪}

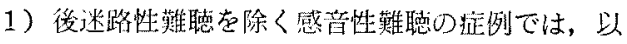
前, 別の機会に症例的に報告したてとがあるが、今回 これを多数例集めて傾向を観察した，気導域値の桨動 にかかわらず，不快レベルが不变である場合と，下降 する場合，および上昇する場合がある，というよりも， 多くの場合感音性難㯖では，不快レベルは，気導䛧の 上昇にかかわらずむしろ下降の偭向を示すかあるいは
不変であるが，聴力損失が非常に大きくなつた場合に は，気導域値の接近によつて押し上げられるように上 昇するものであるといえる. 図1は，ての不快レべル の上昇の㑯向が，どの位の聴力損失のあつたときに起 こつてくるかをみる意味で, 各種感音性難聴耳の気䓕 域值と不快レベルの関係を示したものである４0～50 $\mathrm{dB}$ より聴力損失が大きくなると不快レベルも上軎す る傾向が見られ，それ以下の聴力提失では，ての不快 レベルの上昇の傾向は諗められない。このととはひと つには，内外有毛細胞の機能差に，その原因を求める ことも可能かと思われる。

2）感音性難聴に関して一般的には以上のようなて とがいえるとして，各種の難聴列の間に不快レベルの 発現に幾分差があるのではないかという点で, メニエ ル氏病・老人性難聴・低音性感音性難聴を区別して図 示したものか図 $2 a$ および図 2 bであり,メニエル氏 病では不快レベルは比較的低いレベルに出現し，老人 性難聴では高いレベルに，低音性感音性難聴では広い 範囲に出現していることがわかり，それぞれの難聴の 間の性質の相違, 臨床症状などについて示䍟するとこ ろがあるように思われる。

3）後迷路性難聴の場合は図 3 に示してある。この 種の難聴では，前述したような蚛力損失では説明でき ない程度に不快レベルが上軎するものである，症例は 少ないが，こてで注目しなくてはならないのは，不快 レベルの上昇が，気導域値の障害が軽度のうちから現 われていることで，てのことは，後迷路性難聴では比 較的初期から不快レベルの上显の起こることを示唆し ており，不快レベルの測定が，こうした難聴の早期榇 断に関して，非常に简単で有用な検查法であることを 示している。

\section{むす び}

以上，不快レベルの感音性難聴耳における変動の状 驡および各種難聴耳において，その変動に多少の差の あることを述へた。，特に，後述路性難聴においては早 
期より不快レベルの上昇が現われるため，早期診断法 として簡単かつ有用な方法であると思われることを指
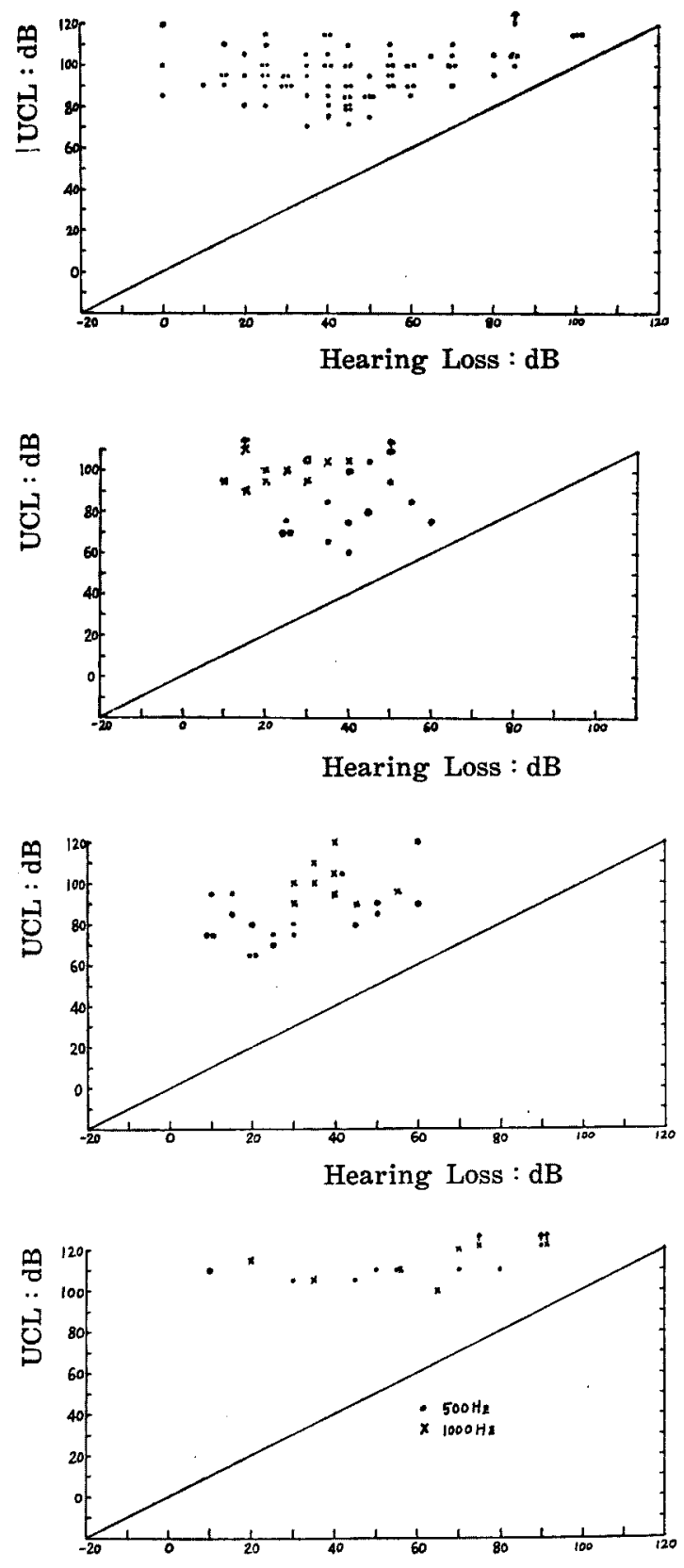

Hearing Loss : $d B$
摘した。

㘣1

各種感音性難聴耳における不快レベル

$(1000 \mathrm{~Hz})$

\section{図 $2 \mathrm{a}$}

病因別にみた感音性難聴耳の不快レベル $(250 \mathrm{~Hz})$

\section{$\times$ 老人性難聴 \\ ○ $x$ ニエル氏病}

- 低音性感音性難聴

\section{图 2 b}

病因別にみた感音性難聴耳の不快レベル $(2000 \mathrm{~Hz})$
图 3

後迷路性難聴耳の不快レベル $(500 \mathrm{~Hz}$ および $1000 \mathrm{~Hz})$ 